\title{
T cell mediated immunity against influenza H5N1 nucleoprotein, matrix and hemagglutinin derived epitopes in H5N1 survivors and non-H5N1 subjects
}

\author{
Pirom Noisumdaeng ${ }^{1,2,3}$, Thaneeya Roytrakul ${ }^{4}$, Jarunee Prasertsopon ${ }^{5}$, Phisanu Pooruk ${ }^{6}$, Hatairat Lerdsamran ${ }^{5}$, \\ Susan Assanasen ${ }^{7}$, Rungrueng Kitphati ${ }^{8}$, Prasert Auewarakul ${ }^{3}$, Pilaipan Puthavathana ${ }^{\text {Corresp. } 3,5}$ \\ ${ }^{1}$ Faculty of Public Health, Thammasat University, Khlong Luang, Pathum Thani, Thailand \\ 2 Thammasat University Research Unit in Modern Microbiology and Public Health Genomics, Thammasat University, Khlong Luang, Pathum Thani, Thailand \\ 3 Department of Microbiology, Faculty of Medicine Siriraj Hospital, Mahidol University, Bangkok-noi, Bangkok, Thailand \\ 4 National Center for Genetic Engineering and Biotechnology, Khlong Luang, Pathum Thani, Thailand \\ 5 Center for Research and Innovation, Faculty of Medical Technology, Mahidol University, Nakhon Pathom, Thailand \\ 6 The Government Pharmaceutical Organization, Biological Product Vaccine Production Plant, Kaengkhoi, Saraburi, Thailand \\ 7 Department of Medicine, Faculty of Medicine Siriraj Hospital, Mahidol University, Bangkok-noi, Bangkok, Thailand \\ 8 Ministry of Public Health, Nonthaburi, Thailand \\ Corresponding Author: Pilaipan Puthavathana \\ Email address: pilaipan.put@mahidol.edu
}

Background. Protection against the influenza virus by a specific antibody is relatively strain specific; meanwhile broader immunity may be conferred by cell-mediated immune response to the conserved epitopes across influenza virus subtypes. A universal broad-spectrum influenza vaccine which confronts not only seasonal influenza virus, but also avian influenza H5N1 virus is promising.

Methods. This study determined the specific and cross-reactive $T$ cell responses against the highly pathogenic avian influenza A (H5N1) virus in four survivors and 33 non-H5N1 subjects including 10 H3N2 patients and 23 healthy individuals. Ex vivo IFN-y ELISpot assay using overlapping peptides spanning the entire nucleoprotein (NP), matrix (M) and hemagglutinin (HA) derived from A/Thailand/1(KAN-1)/2004 (H5N1) virus was employed in adjunct with flow cytometry for determining $T$ cell functions.

Microneutralization (microNT) assay was performed to determine the status of previous H5N1 virus infection.

Results. IFN-y ELISpot assay demonstrated that survivors nos. 1 and 2 had markedly higher T cell responses against H5N1 NP, M and HA epitopes than survivors nos. 3 and 4; and the magnitude of T cell responses against NP were higher than that of $\mathrm{M}$ and HA. Durability of the immunoreactivity persisted for as long as four years after disease onset. Upon stimulation by NP in IFN-ץ ELISpot assay, $60 \%$ of H3N2 patients and $39 \%$ of healthy subjects exhibited a cross-reactive $T$ cell response. The higher frequency and magnitude of responses in H3N2 patients may be due to blood collection at the convalescent phase of the patients. In H5N1 survivors, the effector peptide-specific T cells generated from bulk culture PBMCs by in vitro stimulation displayed a polyfunction by simultaneously producing IFN- $\gamma$ and TNF- $\alpha$, together with upregulation of CD107a in recognition of the target cells pulsed with peptide or infected with rVacNP virus as investigated by flow cytometry.

Conclusions. This study provides an insight into the better understanding on the homosubtypic and heterosubtypic T cell-mediated immune responses in H5N1 survivors and non-H5N1 subjects. NP is an

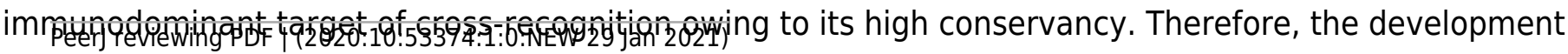


of vaccine targeting the conserved NP may be a novel strategy for influenza vaccine design. 


\section{T cell mediated immunity against influenza H5N1 nucleoprotein, matrix and}

\section{2 hemagglutinin derived epitopes in H5N1 survivors and non-H5N1 subjects}

3 Pirom Noisumdaeng ${ }^{1,2,3}$, Thaneeya Roytrakul ${ }^{4}$, Jarunee Prasertsopon ${ }^{5}$, Phisanu Pooruk ${ }^{6}$,

4 Hatairat Lerdsamran $^{5}$, Susan Assanasen ${ }^{7}$, Rungrueng Kitphati ${ }^{8}$, Prasert Auewarakul ${ }^{3}$ and

5 Pilaipan Puthavathana ${ }^{3,5^{*}}$

$7 \quad{ }^{1}$ Faculty of Public Health, Thammasat University, Khlong Luang, Pathum Thani, Thailand

$8{ }^{2}$ Thammasat University Research Unit in Modern Microbiology and Public Health Genomics,

9 Thammasat University, Khlong Luang, Pathum Thani, Thailand

$10{ }^{3}$ Department of Microbiology, Faculty of Medicine Siriraj Hospital, Mahidol University,

11 Bangkok-noi, Bangkok, Thailand

$12{ }^{4}$ National Center for Genetic Engineering and Biotechnology, Khlong Luang, Pathum Thani,

13 Thailand

$14{ }^{5}$ Center for Research and Innovation, Faculty of Medical Technology, Mahidol University,

15 Nakhon Pathom, Thailand

$16{ }^{6}$ The Government Pharmaceutical Organization, Biological Product Vaccine Production Plant,

17 Kaengkhoi, Saraburi, Thailand

$18{ }^{7}$ Department of Medicine, Faculty of Medicine Siriraj Hospital, Mahidol University, Bangkok-

19 noi, Bangkok, Thailand

$20{ }^{8}$ Ministry of Public Health, Nonthaburi, Thailand

21

$22 *$ Corresponding author:

23 Professor Emer. Pilaipan Puthavathana, Ph.D. 
24 Center for Research and Innovation, Faculty of Medical Technology, Mahidol University, Nakhon

25 Pathom, Thailand, E-mail: pilaipan.put@mahidol.edu

\section{Abstract}

27 Background. Protection against the influenza virus by a specific antibody is relatively strain specific; meanwhile broader immunity may be conferred by cell-mediated immune response to the conserved epitopes across influenza virus subtypes. A universal broad-spectrum influenza vaccine which confronts not only seasonal influenza virus, but also avian influenza H5N1 virus is promising.

Methods. This study determined the specific and cross-reactive $T$ cell responses against the highly pathogenic avian influenza A (H5N1) virus in four survivors and 33 non-H5N1 subjects including $10 \mathrm{H} 3 \mathrm{~N} 2$ patients and 23 healthy individuals. Ex vivo IFN- $\gamma$ ELISpot assay using overlapping peptides spanning the entire nucleoprotein (NP), matrix (M) and hemagglutinin (HA) derived from A/Thailand/1(KAN-1)/2004 (H5N1) virus was employed in adjunct with flow cytometry for determining $\mathrm{T}$ cell functions. Microneutralization (microNT) assay was performed to determine the status of previous $\mathrm{H} 5 \mathrm{~N} 1$ virus infection.

Results. IFN- $\gamma$ ELISpot assay demonstrated that survivors nos. 1 and 2 had markedly higher T cell responses against H5N1 NP, M and HA epitopes than survivors nos. 3 and 4; and the magnitude of $\mathrm{T}$ cell responses against NP were higher than that of M and HA. Durability of the immunoreactivity persisted for as long as four years after disease onset. Upon stimulation by NP in IFN- $\gamma$ ELISpot assay, $60 \%$ of $\mathrm{H} 3 \mathrm{~N} 2$ patients and $39 \%$ of healthy subjects exhibited a crossreactive $\mathrm{T}$ cell response. The higher frequency and magnitude of responses in $\mathrm{H} 3 \mathrm{~N} 2$ patients may be due to blood collection at the convalescent phase of the patients. In H5N1 survivors, the effector peptide-specific $\mathrm{T}$ cells generated from bulk culture PBMCs by in vitro stimulation displayed a 
47 polyfunction by simultaneously producing IFN- $\gamma$ and TNF- $\alpha$, together with upregulation of

$48 \mathrm{CD} 107 \mathrm{a}$ in recognition of the target cells pulsed with peptide or infected with rVac-NP virus as

49 investigated by flow cytometry.

50 Conclusions. This study provides an insight into the better understanding on the homosubtypic

51 and heterosubtypic T cell-mediated immune responses in $\mathrm{H} 5 \mathrm{~N} 1$ survivors and non-H5N1 subjects.

$52 \mathrm{NP}$ is an immunodominant target of cross-recognition owing to its high conservancy. Therefore,

53 the development of vaccine targeting the conserved NP may be a novel strategy for influenza

54 vaccine design.

55

56

57

58

59

60

61

62

63

64

65

66

67

68

69

\section{Introduction}

Influenza A virus infection is common in a wide range of avian and mammalian hosts (Webster et al., 1992; Horimoto \& Kawaoka, 2005; Taubenberger \& Kash, 2010; Long et al., 2019). Some avian influenza A virus subtypes, i.e., H5N1, H5N6, H7N7, H7N9 and H9N2, are able to cross the species barrier and infect humans (Wong \& Yuen, 2006; Abdel-Ghafar et al., 2008; Yu et al.,2013; Puzelli et al., 2014; Pan et al.,2016; Peacock et al., 2019). Among these avian influenza subtypes, the H5N1 highly pathogenic avian influenza (HPAI) virus is the most virulent and the most fatal in humans and animals (Peiris, de Jong \& Guan, 2007; Korteweg \& $G u, 2008)$. The first outbreak of the H5N1 HPAI virus in humans occurred in Hong Kong in 1997. Its re-emergence in 2003 affected several countries in various continents, in particular, the AsiaPacific region (Chan, 2002; Horimoto \& Kawaoka, 2005; Peiris, de Jong \& Guan, 2007). From 2003 to 10 July 2020, the World Health Organization (WHO) reported a cumulative number of 861 human cases with 455 deaths leading to the fatality rate of approximately $53 \%(W H O, 2020)$. A person infected with the H5N1 HPAI virus mostly exhibits severe pneumonia, while 
70 asymptomatic infection or mild illness was scant (Hinjoy et al., 2008; Le et al., 2013). Almost of

71 the cases contracted the H5N1 virus infection through contact with sick or dead poultry. Rare

72 cases of person-to-person transmission have been documented (Ungchusak et al., 2005).

73 Interestingly, nearly all villagers living in the H5N1 outbreak areas are naïve to this virus infection

74 (Hinjoy et al., 2008; Dejpichai et al., 2009), which anticipated that their immune system is naïve

75 to this virus subtype.

76 There were several studies on the immune responses to H5N1 virus infection based on

77 the in vitro or ex vivo system of animal origins (O'Neill et al., 2000; Seo \& Webster, 2001; Seo,

78 Peiris \& Webster, 2002; Droebner et al., 2008; Sawai et al., 2008; Galli et al., 2009; Richards,

79 Chaves \& Sant, 2009; van et al., 2010; Rimmelzwaan \& Katz, 2013; Lin et al., 2013; Ross et al.,

80 2014; Park et al., 2014; Koutsakos, Kedzierska \& Subbarao, 2019). Conversely, there is limited

81 information on the immune responses against $\mathrm{H} 5 \mathrm{~N} 1$ virus infection in humans, particularly in

82 terms of cell-mediated immunity (CMI) which plays an essential role on viral clearance by

83 eliminating the virus-infected cells (Boon et al., 2004; Thomas et al., 2006; Mbawuike, Zhang \&

84 Couch, 2007; Rimmelzwaan \& Katz, 2013; Koutsakos, Kedzierska \& Subbarao, 2019). Several

85 studies demonstrated that a majority of T cells specific to the seasonal H3N2 or H1N1 influenza

86 virus recognize a variety of the viral proteins: nucleoprotein $(\mathrm{NP})$, matrix $(\mathrm{M})$, polymerase $(\mathrm{PB} 1$,

87 PB2, PA), hemagglutinin (HA), neuraminidase (NA) and nonstructural (NS) proteins (Assarsson

88 et al., 2008; Gioia et al., 2008; Kreijtz et al., 2008; Lee et al., 2008; Roti et al., 2008; Babon et al.,

89 2009). The $\mathrm{CD}^{+}$and $\mathrm{CD}^{+} \mathrm{T}^{\mathrm{T}}$ cells which targeted the seasonal influenza viral proteins also cross-

90 recognized the internal conserved epitopes in H5N1 proteins: PB1, PB2, PA, NS, and in particular,

91 the NP and M which are the immunodominant targets (Assarsson et al., 2008; Gioia et al., 2008;

92 Kreijtz et al., 2008; Lee et al., 2008; Roti et al., 2008; Babon et al., 2009). Furthermore, the cross- 
93 reactive memory $\mathrm{CD}^{+}{ }^{+} \mathrm{T}$ cells recognized the variable surface glycoprotein $\mathrm{HA}$ and NA (Roti et

94 al., 2008). Nevertheless, this information was generated by using immune cells from healthy

95 donors due to an inability to access the blood specimens from H5N1 patients. Therefore, the

96 information obtained may not represent the immune response developed after H5N1 natural

97 infection.

98 In this study, we assessed the T cell response to H5N1 NP, M, and HA epitopes using 99 archival peripheral blood mononuclear cells (PBMCs) from individuals who recovered from H5N1

100 HPAI viral infections from 2004 to 2005 using flow cytometry and IFN- $\gamma$ ELISpot assay.

101 Moreover, we investigated the cross-reactive $\mathrm{T}$ cell response to H5N1 proteins in individuals who

102 recovered from the H3N2 influenza virus infection. Our study may aid the design of a candidate $\mathrm{T}$

103 cell-based universal vaccine for broad-viral subtype protection.

104

105 Materials and Methods

106 Ethical issue

107 This study was approved by Institutional Review Boards from the Faculty of Medicine

108 Siriraj Hospital, Mahidol University, under approval number Si213/2005. Informed consent was

109 obtained from all non-H5N1 individuals and H5N1 survivors or their parents for participation in

110 this study (Kitphati et al., 2009; Noisumdaeng et al., 2014).

111

\section{Human subjects and blood specimen}

113 Sera, plasma and peripheral blood mononuclear cells (PBMCs) were obtained from 37

114 participants including four H5N1 Thai survivors, $10 \mathrm{H} 3 \mathrm{~N} 2$ patients and 23 healthy individuals

115 (Kitphati et al., 2009; Noisumdaeng et al., 2013; Noisumdaeng et al., 2014). Survivor nos. 1 and 
1162 were adults, while survivor nos. 3 and 4 were young children. All of them were infected with

117 H5N1 clade 1 virus. A total of 20 sequential blood samples were collected from these survivors at

118 intervals for up to four years after disease onset (Kitphati et al., 2009). The demographic data of

119 the H5N1 survivors and time at blood specimen collection are shown in supplementary Table S1A.

120 The H3N2 patients were diagnosed by real time reverse transcription-polymerase chain reaction

121 (real time RT-PCR), and virus isolation together with serodiagnosis when possible. Demographic

122 data of non-H5N1 infected subjects is presented in supplementary Table S1B. Sera and plasma

123 samples were kept frozen at $-20^{\circ} \mathrm{C}$ until used. PBMCs were separated from anti-coagulated blood

124 using Ficoll-Hypaque, (IsoPrep, Robbins Scientific Corporation, Sunnyvale, CA) density gradient

125 centrifugation and stored in a freezing medium containing 10\% DMSO (Sigma, MO) in fetal

126 bovine serum (FBS) (Gibco $\left.{ }^{\circledR}, \mathrm{NY}\right)$ and cryopreserved in liquid nitrogen.

128 Recombinant vaccinia viruses

129 Recombinant vaccinia virus carrying H5N1 NP gene inserted in the pSC11 plasmid

130 backbone (rVac-NP virus) or the recombinant virus carrying only the pSC11 backbone (rVac-

131 pSC11 virus) were constructed in our laboratory. The viruses were propagated and titrated in

132 Thymidine kinase negative $\left(\mathrm{TK}^{-}\right)$cells maintained in Dulbecco's modified eagle medium (DMEM)

133 (Gibco) supplemented with 10\% FBS plus penicillin and streptomycin (Noisumdaeng et al., 2013;

134 Noisumdaeng et al., 2014). The virus stocks were kept at $-80^{\circ} \mathrm{C}$ until used.

Microneutralization (microNT) assay for antibody detection

138 the A/Thailand/1(KAN-1)/2004 (H5N1) clade 1 (KAN-1 virus), A/Thailand/Siriraj-Rama- 
139 TT/2004 [A/New Caledonia/20/1999 (H1N1)-like virus], and A/Siriraj ICRC/SI-154/2008

140 [A/Brisbane/10/2007 (H3N2)-like virus]. The assay protocol was described previously (Kitphati

141 et al., 2009; Lerdsamran et al., 2011; Noisumdaeng et al., 2014).

143 Designing the overlapping peptides and peptide-pool matrix

144 Overlapping peptides spanning the entire NP, M1, M2 and HA proteins of H5N1 KAN-1

145 virus (GenBank accession no., AAV35112, AAV35110, AAV35111 and AAS65615, respectively)

146 were synthesized in the PEPscreen ${ }^{\circledR}$ custom peptide libraries format (Sigma-Genosys, Singapore).

147 According to supplementary Table S2, the amino acid sequence identities of each protein were

148 conserved among various H5N1 viruses circulating in Thailand during the study period.

149 According to the manufacturer, all peptides were analyzed by MALDI-TOF mass spectrometry

150 and their average crude purity is greater than $70 \%$. Each peptide was 20 amino acids long with 10

151 amino acid residues overlapping, except the last peptide of the protein which may be shorter. There

152 were a total of $49 \mathrm{NP}$ peptides, $25 \mathrm{M} 1$ peptides, $10 \mathrm{M} 2$ peptides and $56 \mathrm{HA}$ peptides as shown in

153 supplementary Tables S3A-S3C. Peptide powder was dissolved in dimethyl sulfoxide (DMSO,

154 Sigma) to the concentration of $50 \mathrm{mg} / \mathrm{ml}$, then aliquot and kept at $-80^{\circ} \mathrm{C}$. The concentrate peptide

155 solution was further diluted in serum-free Roswell Park Memorial Institute 1640 medium (RPMI,

156 Gibco) to the concentration of $2.5 \mathrm{mg} / \mathrm{ml}$ and stored at $-80^{\circ} \mathrm{C}$ in aliquots. These peptides were

157 mixed into individual pools according to the two-dimensional matrix system as shown in

158 supplementary Tables S3D-S3F. Each peptide pool contained an individual peptide at working

159 concentration of $40 \mu \mathrm{g} / \mathrm{ml}$. There were a total of 14 pools (A1-A7 and B1-B7) for NP, 12 pools

160 (A1-A6 and B1-B6) for M and 15 pools (A1-A8 and B1-B7) for HA. The DMSO concentration

161 in each assay was less than $0.1 \%(\mathrm{v} / \mathrm{v})$. 


\section{Ex vivo IFN- $\gamma$ enzyme-linked immunospot (ELISpot) assay}

164 IFN- $\gamma$ ELISpot assay was performed to demonstrate the T cell responses against H5N1-

165 derived peptides among $\mathrm{H} 5 \mathrm{~N} 1$ survivors and non-H5N1 subjects. A 96-well polyvinylidene

166 difluoride (PVDF) ELISPOT plate (Multiscreen ${ }^{\mathrm{TM}}$ IP, MAIPS4510, Millipore, USA) was coated

167 with mouse monoclonal anti-human IFN- $\gamma$ 1-D1K (Mabtech AB, Stockholm, Sweden) at a

168 concentration of $15 \mu \mathrm{g} / \mathrm{ml}$ overnight at $4^{\circ} \mathrm{C}$, followed by blocking with $\mathrm{RPMI}$ supplemented with

$16910 \%$ FBS for 2 hours. After the blocking solution was discarded, the PBMC suspensions were

170 added at the concentration of $3 \times 10^{5}$ cells/100 $\mu 1 /$ well. Thereafter, peptide pool at a final

171 concentration of $4 \mu \mathrm{g} / \mathrm{ml}$ (for screening of $\mathrm{T}$ cell activity) or individual peptide (for peptide specific

172 activity of $\mathrm{T}$ cells) at a final concentration of $10 \mu \mathrm{g} / \mathrm{ml}$ was added into each well. PBMCs

173 incubated with medium only served as the negative control, whereas PBMCs treated with 1 and

$17410 \mu \mathrm{g}$ of phytohemagglutitin (PHA) (Sigma) served as the positive controls. After incubation for

175 14-16 hours, PBMCs were removed, and the plate was washed with $0.05 \%$ Tween-20 in PBS

176 (PBST). The biotin conjugated-anti-IFN- $\gamma$ (7-B6-1-biotin, Mabtech) was used as the primary

177 antibody to bind the released IFN- $\gamma$ absorbed on the membrane lining the plate bottom.

178 Streptavidin-labelling alkaline phosphatase was used as the secondary antibody and followed by

179 BCIP/NBT plus (Mabtech) as the chromogenic substrate. The reaction plate was incubated until

180 purple spots were visible on the membrane, and then the reaction was terminated. The spots which

181 represent the secreted IFN- $\gamma$ producing $\mathrm{T}$ cells were counted and analyzed using a KS ELISpot

182 version 4.11 program of an ELISpot plate reader (KS ELISpot, Zeiss, Munich, Germany). The T

183 cell activity was considered positive when the number of spot forming cells (SFCs) in the reaction

184 wells was at least two times greater than those of the negative control wells. 


\section{Functional assays of H5N1-specific $\mathrm{T}$ cells}

The $\mathrm{T}$ cell functional assay was demonstrated by intracellular cytokine staining (ICS) and

188

189

190

193

194

195

flow cytometry of peptide-specific polyclonal $\mathrm{T}$ cell lines (effector $\mathrm{T}$ cells) which were generated as bulk culture by stimulating the PBMCs with an individual specific peptide. The study design was shown in supplementary Fig. S1, and the detailed method was as followed:

- Establishment of Epstein-Barr virus (EBV) transformed B cell lines (TBCLs)

Autologous TBCLs were used as the target cells for $\mathrm{T}$ cell functional assay by flow cytometry. TBCLs were established by infecting PBMCs with EBV from supernatant of B95-8 culture in RPMI supplemented with $10 \%$ FBS and in the presence of cyclosprorin A. Clumps of transformed B lymphocytes generally appeared after 2-3 weeks of infection. TBCLs could multiply indefinitely, a condition known as immortalization.

- Establishment and maintenance of peptide-specific T cell lines

A bulk culture of specific polyclonal T cell line was generated by stimulating PBMCs with peptide and used as a source of the effector T cells. Frozen PBMCs of an number of 5-10x106 cells were thawed and divided into two portions comprising $20 \%$ and $80 \%$ of total cells. The $20 \%$ portion were pulsed with $100 \mu \mathrm{g} / \mathrm{ml}$ of peptide before mixing with the $80 \%$ portion. The suspension of cell mixture was added into a 6 -well culture plate at the amount of $2-3 \times 10^{6}$ cells/well in 10\% NHS RPMI supplemented with $25 \mathrm{ng} / \mathrm{ml} \mathrm{IL-7} \mathrm{(Peprotec,} \mathrm{USA)} \mathrm{and} 50 \mathrm{U} / \mathrm{ml} \mathrm{IL-2} \mathrm{(Chiron,}$ Netherlands).

Clumps of proliferating T cells should be seen in the culture at approximately 2 weeks after cultivation, i.e., peptide-specific polyclonal T cell line was established. T cell lines were expanded 
207 by stimulation with autologous gamma irradiated peptide-pulsed TBCLs plus irradiated allogeneic

208 PBMCs (2,000 rad using cesium source).

The peptide-pulsed autologous TBCLs or TBCLs infected with rVac-NP virus were used

211 as the target cells or antigen presenting cells (APCs) for investigating the function of peptide-

212 specific $\mathrm{T}$ cells by flow cytometry. The unpulsed TBCLs or TBCLs infected with rVac-pSC11

213 virus were used as the negative target cell control. Pellets of TBCLs were pulsed with $100 \mu \mathrm{g} / \mathrm{ml}$

214 of specific peptides for 1 hour, followed by washing and re-suspending with $10 \%$ FBS RPMI. For

215 preparing recombinant vaccinia virus infected TBCLs, the cells were infected with rVac-NP or

216 rVac-pSC11 virus at a multiplicity of infection (moi) of 3. After adsorption for 1 hour 30 minutes

217 at $37^{\circ} \mathrm{C}$, the infected cells were washed and re-suspended with $2 \%$ FBS RPMI and incubated

218 overnight prior to functional assay by flow cytometry.

- Intracellular cytokine staining (ICS) by flow cytometry

The flow cytometry assay comprised the FACS tubes of the polyclonal peptide-specific T

cell lines (effector cells) stimulated with target cells (TBCLs pulsed with specific peptide or

222 TBCLs infected with rVac-NP virus), and the control tubes including the effector cell alone,

223 effector cells plus unpulsed TBCLs or effector cells plus rVac-pSC11 virus infected TBCLs.

224 Staphylococcal enterotoxin B (SEB) was used as the positive stimulation control. Briefly, $1 \times 10^{5}$

225 effector cells were mixed with $1 \times 10^{6}$ target cells in a one ml volume (effector: target ratio of 1:10).

226 The cell mixtures were incubated with anti-CD107a monoclonal antibody conjugated with FITC

227 (BD Bioscience) for 2 hours before adding with the mixture of monensin and brefeldin $\mathrm{A}$ at the

228 final concentration of $10 \mu \mathrm{g} / \mathrm{ml}$, and further incubated for 5 hours. The cells were washed with

229 FACS washing buffer (1\% FBS, 0.5\% NHS, $0.5 \mathrm{mM}$ EDTA, $0.1 \% \mathrm{NaN}_{3}$ in PBS) and treated with 
230 FACS Permeabilizing Solution II (BD Biosciences) for 15 minutes in the dark in order to fix and

231 permeabilize the cells. Thereafter, the cells were washed and stained with a cocktail of monoclonal

232 antibodies: anti-CD4 PerCP or anti-CD8 PerCP, anti-IFN- $\gamma$ APC and anti-TNF- $\alpha$ PE monoclonal

233 antibodies (BD Biosciences). The $\mathrm{CD}^{+}$or $\mathrm{CD} 8^{+} \mathrm{T}$ cell populations producing IFN- $\gamma, \mathrm{TNF}-\alpha$ and

234 upregulation of CD107a degranulation marker were analyzed by FACSCalibur ${ }^{\mathrm{TM}}$ instrument by

235 using CellQuest ${ }^{\mathrm{TM}}$ program (BD Biosciences).

236

237 Data analysis

238

The data graphs on IFN- $\gamma$ T cell responses in H5N1 survivors and non-H5N1 subjects were generated using GraphPad Prism software version 4.0. The difference in the magnitude of responses (SFCs/106 PBMCs) between the $\mathrm{H} 3 \mathrm{~N} 2$ patients and healthy subjects was analyzed by

241 Mann-Whitney U test. The statistically significant difference was obtained when the $P$-value was 242 less than 0.05 .

\section{Results}

\section{Screening for $T$ cell response against $N P, M$ and $H A$ in $H 5 N 1$ survivors}

Pool peptides derived from H5N1 NP, M or HA amino acid sequences were employed to screen for reactive $\mathrm{T}$ cell response in $\mathrm{H} 5 \mathrm{~N} 1$ survivors using IFN- $\gamma$ ELISpot assay. The results showed that PBMCs from the four H5N1 survivors elicited T cell responses against NP, M and HA peptide pools as shown in Fig. 1A, 1B and 1C, respectively. The number of IFN- $\gamma$ producing

251 T cells stimulated by NP pooled peptides was higher than those of M and HA, which suggested

252 that NP was more immunogenic in the induction of $\mathrm{T}$ cell responses. We also found that the $\mathrm{T}$ cell 
253 response in adults (survivor nos. 1 and 2) was stronger than that in children (survivor nos. 3 and

254 4). The $\mathrm{T}$ cell reactivity against NP and M peptides persisted for as long as 4 years after onset of 255 disease as followed that far (Fig. 1A and 1B). All four H5N1 survivors had markedly high 256 neutralizing antibody titers against $\mathrm{H} 5 \mathrm{~N} 1$ virus as demonstrated by an ELISA-based microNT 257 assay. Moreover, they also contained neutralizing antibodies to seasonal H1N1 and/or H3N2 258 viruses as shown in supplementary Table S1.

259

\section{Determining the $T$ cell activity against specific epitopes on NP, M and HA}

Due to strong responses to pooled NP, M and HA peptides, H5N1 survivor nos. 1 and 2 epitopes recognized by survivor no. 1 were $\mathrm{NP}_{1-20}, \mathrm{NP}_{111-130}$ (Fig. 2A, left panel), $\mathrm{M}_{121-140}, \mathrm{M}_{201-}$

$\mathrm{NP}_{411-430}$ (Fig. 2B, left panel), $\mathrm{M1}_{1-20}, \mathrm{M}_{91-110}, \mathrm{Ml}_{241-252}$ (Fig. 2B, middle panel), $\mathrm{HA}_{41-60}, \mathrm{HA}_{251-}$ 270 and $\mathrm{HA}_{291-310}$ (Fig. 2B, right panel). However, the magnitude of responses to NP peptides was higher than those to M and HA peptides, indicating that NP is more immunogenic and putatively 268 a highly immunogenic protein target for $\mathrm{T}$ cell responses. Based on serial PBMC samples, it was demonstrated that the reactivity of the peptide-reactive $\mathrm{T}$ cells could persist for at least 4 years after disease onset. The summary of magnitude and longevity of $\mathrm{T}$ cell responses are shown in 271 supplementary Table S4.

\section{Cross-reactive $T$ cell responses against H5N1 NP peptides in non-H5N1 individuals}

This study carried out the cross-reactive T cell response to H5N1 NP peptides in 33 non- 
27623 healthy individuals. These subjects were confirmed for their H5N1 seronegativity by microNT

277 assay (supplementary Table S1B). PBMCs were tested against the 49 overlapping peptides

278 spanning the entire H5N1 NP by IFN- $\gamma$ ELISpot assay. The results demonstrated that the

279 magnitude of total cross-reactive T cells varied considerably between individuals. The mean of $e x$

280 vivo IFN- $\gamma$ responses was 102 and $51 \mathrm{SFCs} / 10^{6} \mathrm{PBMCs}$ in $\mathrm{H} 3 \mathrm{~N} 2$ patients and healthy subjects,

281 respectively; and the mean of responses was statistically significant different between both groups

282 (Mann-Whitney U test; $\mathrm{p}<0.05$ ) (Fig. 3).

283

The ELISpot assay with individual candidate NP peptide was conducted to identify the

284 peptide-specific reactivity. From a total of 33 non-H5N1 subjects, six (60\%) of 10 H3N2 patients

285 and nine (39\%) of 23 healthy subjects responded to the stimulation by NP peptides derived from

$286 \mathrm{H} 5 \mathrm{~N} 1 \mathrm{KAN}-1$ virus. In total, 5 peptides were recognized, i.e., $\mathrm{NP}_{111-130}, \mathrm{NP}_{221-230}, \mathrm{NP}_{311-330}, \mathrm{NP}_{401-}$

287420 and $\mathrm{NP}_{481-498}$ as indicated in Table 1. However, each responder recognized only 1 or 2 peptides. 288

\section{H5N1 NP-specific T cells elicited cytokine production and cytotoxic function}

The effector cells in bulk culures of peptide-specific $\mathrm{T}$ cell lines (generated by clonal expansion of T cells after in vitro stimulation [IVS] of PBMCs from H5N1 survivors no. 1 with $\mathrm{NP}_{1-20}$ and survivors no. 2 with $\mathrm{NP}_{411-430}$ peptide) were investigated by flow cytometry for IFN- $\gamma$ and TNF- $\alpha$ productions, and the upregulation of CD107a, the degranulating marker of cytotoxic

294 function, and additionally their immunophenotypes. The result showed that both CD4 $4^{+}$and $\mathrm{CD} 8^{+}$

295 T cells from survivor nos. 1 and 2 expressed IFN- $\gamma^{+}$and TNF- $\alpha^{+}$in recognition to the target cells 296 infected with rVac-NP virus or pulsed with $\mathrm{NP}_{1-20}$ (for survivor no.1) or $\mathrm{NP}_{411-430}$ (for survivor 297 no.2). Nevertheless, only CD $8^{+} \mathrm{T}$ cells sufficiently expressed CD $107 \mathrm{a}^{+}$, while the expression level 298 was poor for the $\mathrm{CD}^{+}{ }^{+} \mathrm{T}$ cells (Fig. 4, supplementary Fig. S2 and supplementary Table S5). 
300 Identity of NP epitope sequences among different influenza virus subtypes

Amino acid sequences of the H5N1 NP peptides that were recognized by the H5N1

302 survivors and non-H5N1 subjects were aligned and analyzed for their identities with those derived

303 from the human influenza viruses as shown in Table 2. The $\mathrm{H} 5 \mathrm{~N} 1 \mathrm{NP}_{1-20}$ and $\mathrm{NP}_{401-420}$ amino acid

304 sequences were identical to those of the $\mathrm{H} 1 \mathrm{~N} 1 \mathrm{pdm}$ virus, while the $\mathrm{NP}_{111-130}$ and $\mathrm{NP}_{221-240}$ were 305 identical to the $\mathrm{H} 3 \mathrm{~N} 2$ virus. As such, the $\mathrm{H} 5 \mathrm{~N} 1$ cross-reactive $\mathrm{T}$ cells found in non-H5N1 subjects

$306\left(\mathrm{NP}_{111-130}, \mathrm{NP}_{221-240}, \mathrm{NP}_{311-330}, \mathrm{NP}_{401-420}\right.$, and $\mathrm{NP}_{481-498}$ peptides) might be generated from previous

307 exposure to the common epitopes between the H5N1 virus and the seasonal H1N1 or H3N2

308 viruses. Cross reactivity for the $\mathrm{NP}_{111-130}$ and $\mathrm{NP}_{221-240}$ was found in higher frequency than the

309 other peptides. Interestingly, the $\mathrm{NP}_{411-430}$ (TFSVQRNLPFERATIMAAFT) was a unique epitope

310 recognized by H5N1 survivors only.

312 Discussion

Thailand reported $25 \mathrm{H} 5 \mathrm{~N} 1$ infected cases with 17 deaths (fatality rate $68 \%$ ) to WHO

314 during the outbreak that lasted from 2004 to 2006. No H5N1 patient has occurred since then. We

315 could access four of the eight survivors, whose sequential blood samples were collected at

316 approximately six-month intervals. Using cryopreserved PBMC samples from four H5N1

317 survivors and 23 non-H5N1 subjects, the present study employed IFN- $\gamma$ ELISpot assay and flow

318 cytometry to investigate cell-mediated immune responses targeting NP, M and HA derived from

319 HPAI H5N1 virus strain A/Thailand/1(KAN-1)/2004 (H5N1) (Puthavathana et al., 2005; Kitphati

320 et al., 2009). Our analyses on the amino acid sequence identities of various H5N1 viruses isolated

321 in Thailand between 2004 and 2008 against the KAN-1 virus showed that the peptides used were 
322 relatively conserved across the circulating viruses during the study period. NP was the most

323 conserved protein with the degree of identities varying from $99.1-100 \%$, whereas the identities

324 among M1, M2, and HA proteins ranging from $98.8-100 \%$, 96.9-100\%, and $98.7-99.8 \%$,

325 respectively. The study demonstrated that adult survivors (nos. 1 and 2) had stronger T cell

326 response than the children survivors (nos. 3 and 4) which could be explained by few reasons: 1)

327 adults were previously expose to the seasonal influenza virus infection or vaccination; therefore,

328 the pre-existing cross-reactive $\mathrm{T}$ cells might be boosted after $\mathrm{H} 5 \mathrm{~N} 1$ infection, and also adding up

329 with more number of H5N1-specific T cells; 2) young children generated a lower number of

330 influenza virus-specific memory $\mathrm{T}$ cells compared to adults; or the memory $\mathrm{T}$ cells from children

331 had shorter half-life; and 3) young children (survivor no. 3) who developed mild disease after

332 H5N1 virus infection might generate a lower number of specific memory $\mathrm{T}$ cells than adult

333 survivors who developed severe disease. It has been previously reported that the $2009 \mathrm{H} 1 \mathrm{~N} 1 \mathrm{pdm}$

334 patients who developed severe disease elicited higher levels of circulating influenza virus-specific

$335 \mathrm{CD}^{+} \mathrm{T}$ cells to NP and $\mathrm{M}$ when compared to the cases with mild disease as measured by ELISpot

336 assay (Zhao et al., 2012).

337 The total number of IFN- $\gamma$ reactive $\mathrm{T}$ cells against $\mathrm{NP}$ was higher than that of $\mathrm{M}$ and HA

338 as demonstrated in two H5N1 adult survivors by ELISpot assay using 20 mers-overlapping pooled

339 peptides, which suggested that NP was more immunogenic in the induction of $\mathrm{T}$ cell response. NP

340 is the most abundant viral protein synthesized in the infected cells. It contains several

341 immunodominant epitopes that could stimulate both the humoral and cell-mediated immune

342 responses. As such, NP was identified as the major target of subtype-specific and cross-subtypic

$343 \mathrm{CD}^{+}$and cytotoxic $\mathrm{CD} 8^{+} \mathrm{T}$ lymphocytes as reported by several groups of previous investigators

344 (Kreijtz et al., 2008; Lee et al., 2008; Rimmelzwaan \& Katz, 2013; Roti et al.,2008). Our result of 
345 the $1^{\text {st }}$ round ELISpot assay using pooled peptides was confirmed by the $2^{\text {nd }}$ round ELISpot assay

346 using individual peptides. T cell responses could last longer than 4 years after disease onset for as

347 far as the PBMC samples were available. Using individual peptide, our results showed that each

348 survivor recognized different peptides, suggesting that their HLA or their repertoire of specific T

349 cells were different.

350 Up until the present day, the H5N1-specific T cell epitopes are not well characterized due 351 to the small number of H5N1 survivors. Powell, et al. (Powell et al., 2012) could identify three

352 H5 HA-specific $\mathrm{T}$ cell epitopes $\left(\mathrm{HA}_{160-177}, \mathrm{HA}_{344-364}\right.$ and $\left.\mathrm{HA}_{439-456}\right)$ from $\mathrm{H} 5 \mathrm{~N} 1$ asymptomatic

353 cases; while Sun, et al. (Sun et al., 2010) could identify only one H5 HA-specific T cell epitope

354 (HA 205-214). However, our study was confined to the H5N1 NP peptides according to the limited

355 amount of PBMCs available and the high immunogenicity of NP epitopes. Amino acid sequence

356 identity of greater than $90 \%$ was found across NP proteins of various influenza virus subtypes

357 (Noisumdaeng et al., 2014). Among $49 \mathrm{NP}$ overlapping peptides, three peptides $\left(\mathrm{NP}_{1-20}, \mathrm{NP}_{111-130}\right.$

358 and $\left.\mathrm{NP}_{411-430}\right)$ were identified among the four $\mathrm{H} 5 \mathrm{~N} 1$ survivors, and five peptides $\left(\mathrm{NP}_{111-130}, \mathrm{NP}_{221-}\right.$

359 230, $\mathrm{NP}_{311-330}, \mathrm{NP}_{401-420}$ and $\left.\mathrm{NP}_{481-498}\right)$ among 33 non-H5N1 subjects. Interestingly, only one

360 peptide, $\mathrm{NP}_{111-130}$, could be identified in both $\mathrm{H} 5 \mathrm{~N} 1$ survivors and non-H5N1 subjects. Based on

361 A/Viet Nam/CL26/2004 (H5N1) sequence, the study in healthy Vietnamese and English subjects

362 demonstrated the cross-reactive $\mathrm{CD}^{+} \mathrm{T}$ cells against $\mathrm{H} 5 \mathrm{~N} 1 \mathrm{NP}_{221-238}, \mathrm{NP}_{404-420}$ and $\mathrm{NP}_{478-493}$ as

363 determined by ELISpot assay (Lee et al., 2008). Moreover, the cross-reactive $\mathrm{CD}^{+} \mathrm{T}$ cells against

364 H5N1 $\mathrm{NP}_{401-420}$ and $\mathrm{NP}_{113-132}$ were demonstrated in the healthy Caucasian descent based on

365 A/Vietnam/1203/2004 H5N1 (VN1203) as determined by tetramer-guide epitope mapping. The

$366 \mathrm{NP}_{401-420}$ was restricted to HLA-DR0404; while $\mathrm{NP}_{113-132}$ was restricted to HLA-DR1101 (Roti et 
367 al., 2008). However, the NP epitope variants which could escape from the T cell recognition have

368 been reported (Rimmelzwaan et al., 2004; Berkhoff et al., 2007).

369 We further investigated the effector functions and immunophenotypes of the NP peptide-

370 specific $\mathrm{T}$ cells by flow cytometry. The $\mathrm{NP}_{1-20}$ and $\mathrm{NP}_{411-430}$ peptides could stimulate both $\mathrm{CD} 4^{+}$

371 and $\mathrm{CD} 8^{+} \mathrm{T}$ cell subsets in survivors, leading to clonal expansion and a high degree of polyfunction

372 by simultaneously producing IFN- $\gamma$ and TNF- $\alpha$, and together with an upregulation of CD107a in

373 recognition of the target cells pulsed with peptide or infected with rVac-NP virus. Since our

374 peptides are 20 amino acids long; they might bind to both HLA class I (optimal epitope are 8-12

375 amino acids long) and class II (optimal epitope are 12-18 amino acids long) and lead to activation

376 of $\mathrm{CD}^{+}$and $\mathrm{CD} 8^{+}$memory $\mathrm{T}$ cells. It is implied that NP protein expressed in the rVac-NP virus

377 infected TBCLs is naturally processed and presented in association with HLA to the effector T

378 cells (Jameson, Cruz \& Ennis, 1998). Importantly, it is uncertain that the induction of such

379 polyfunctional $\mathrm{T}$ cell populations might be associated with the recovery from severe diseases in

380 our H5N1 survivors. The amino acid sequences of the avian H5N1 internal proteins were closely

381 identical to those of the seasonal H1N1, H3N2 and H1N1pdm viruses; exposure to seasonal

382 influenza virus infection or vaccination can generate a pool of cross-reactive memory $\mathrm{CD}^{+}$and

$383 \mathrm{CD}^{+} \mathrm{T}$ cells which are capable of recognizing a number of conserved internal proteins form avian

384 H5N1 virus.

385

386 Conclusions

The broader vaccines that rely on the induction of $\mathrm{T}$ cell-based immunity against conserved

epitopes would provide broader partial protection, restrict the viral diversity in the infected host and help lower severity and mortality against overwhelming pandemic influenza virus infection. 
390 Our present study provides insight into a better understanding of the homosubtypic and

391 heterosubtypic T cell-mediated immune responses against H5N1 virus in H5N1 survivors and non-

392 H5N1 subjects. NP is an immunodominant target of cross-recognition owing to its high

393 conservancy. Therefore, the development of vaccine targeting the conserved NP may be a novel

394 strategy for influenza vaccine design.

395

396 Acknowledgements

397 We would like to thank all subjects who participated in the study. We thank all medical

398 staff from Department of Disease Control, Ministry of Public Health for their help in specimen

399 collection from H5N1 survivors and research assistants at Siriraj Influenza Cooperative Research

400 Center, Department of Microbiology, Faculty of Medicine Siriraj Hospital, Mahidol University for

401 kindly supporting reagents, materials and techniques. P.N. specially thanks Thammasat University

402 Research Unit in Modern Microbiology and Public Health Genomics, Thammasat University.

403

404

References

405

Assarsson E, Bui HH, Sidney J, Zhang Q, Glenn J, Oseroff C, Mbawuike IN, Alexander J,

Newman MJ, Grey H, Sette A. 2008. Immunomic analysis of the repertoire of T-cell specificities for influenza A virus in humans. Journal of Virology 82(24):12241-51 DOI 10.1128/JVI.01563-08.

Babon JA, Cruz J, Orphin L, Pazoles P, Co MD, Ennis FA, Terajima M. 2009. Genomewide screening of human T-cell epitopes in influenza A virus reveals a broad spectrum of CD4(+) T-cell responses to internal proteins, hemagglutinins, and neuraminidases. Human Immunology 70(9):711-21 DOI 10.1016/j.humimm.2009.06.004. 
413 Berkhoff EG, Geelhoed-Mieras MM, Verschuren EJ, van Baalen CA, Gruters RA,

414 Fouchier RA, Osterhaus AD, Rimmelzwaan GF. 2007. The loss of immunodominant

415 epitopes affects interferon-gamma production and lytic activity of the human influenza virus-

416 specific cytotoxic T lymphocyte response in vitro. Clinical Experimental Immunology

417 148(2):296-306 DOI 10.1111/j.1365-2249.2007.03340.x.

418 Boon AC, de Mutsert G, van Baarle D, Smith DJ, Lapedes AS, Fouchier RA, Sintnicolaas

419 K, Osterhaus AD, Rimmelzwaan GF. 2004. Recognition of homo- and heterosubtypic

420 variants of influenza A viruses by human CD8+ T lymphocytes. Journal of Immunology

421 172(4):2453-60 DOI 10.4049/jimmunol.172.4.2453.

422 Chan PK. 2002. Outbreak of avian influenza A(H5N1) virus infection in Hong Kong in

423 1997. Clinical Infectious Diseases 1:34 Suppl 2:S58-S64 DOI 10.1086/338820.

424 Dejpichai R, Laosiritaworn Y, Phuthavathana P, Uyeki TM, O'Reilly M, Yampikulsakul N,

425 Phurahong S, Poorak P, Prasertsopon J, Kularb R, Nateerom K, Sawanpanyalert N,

426 Jiraphongsa C. 2009. Seroprevalence of antibodies to avian influenza virus A (H5N1)

427 among residents of villages with human cases, Thailand, 2005. Emerging Infectious Diseases

$428 \quad$ 15(5):756-60 DOI 10.3201/eid1505.080316.

429

430

431

432

433

434

435

Droebner K, Haasbach E, Fuchs C, Weinzierl AO, Stevanovic S, Büttner M, Planz O. 2008. Antibodies and CD4(+) T-cells mediate cross-protection against H5N1 influenza virus infection in mice after vaccination with a low pathogenic H5N2 strain. Vaccine 26(52):696574 DOI 10.1016/j.vaccine.2008.09.051.

Galli G, Medini D, Borgogni E, Zedda L, Bardelli M, Malzone C, Nuti S, Tavarini S, Sammicheli C, Hilbert AK, Brauer V, Banzhoff A, Rappuoli R, Del Giudice G, Castellino F. 2009. Adjuvanted H5N1 vaccine induces early CD4+ T cell response that 
436

437

438

439

440

441

442

443

444

445

446

447

448

449

450

451

452

453

454

455

456

457

predicts long-term persistence of protective antibody levels. Proceedings of the National Academy of Sciences of the United States of America. 106(10):3877-82 DOI 10.1073/pnas.0813390106.

Gioia C, Castilletti C, Tempestilli M, Piacentini P, Bordi L, Chiappini R, Agrati C, Squarcione S, Ippolito G, Puro V, Capobianchi MR, Poccia F. 2008. Cross-subtype immunity against avian influenza in persons recently vaccinated for influenza. Emerging Infectious Diseases 14(1):121-8 DOI 10.3201/eid1401.061283.

Hinjoy S, Puthavathana P, Laosiritaworn Y, Limpakarnjanarat K, Pooruk P, Chuxnum T, Simmerman JM, Ungchusak K. 2008. Low frequency of infection with avian influenza virus (H5N1) among poultry farmers, Thailand, 2004. Emerging Infectious Diseases 14(3):499-501 DOI 10.3201/eid1403.070662.

Horimoto T, Kawaoka Y. 2005. Influenza: lessons from past pandemics, warnings from current incidents. Nature Review Microbiology 3(8):591-600 DOI 10.1038/nrmicro1208

Jameson J, Cruz J, Ennis FA. 1998. Human cytotoxic T-lymphocyte repertoire to influenza A viruses. Journal of Virology 72(11):8682-9 DOI 10.1128/JVI.72.11.8682-8689.1998.

Kitphati R, Pooruk P, Lerdsamran H, Poosuwan S, Louisirirotchanakul S, Auewarakul P, Chokphaibulkit K, Noisumdaeng P, Sawanpanyalert P, Puthavathana P. 2009. Kinetics and longevity of antibody response to influenza A H5N1 virus infection in humans. Clinical and Vaccine Immunology 16(7):978-81 DOI 10.1128/CVI.00062-09.

Korteweg C, Gu J. 2008. Pathology, molecular biology, and pathogenesis of avian influenza A (H5N1) infection in humans. The American Journal of Pathology 172(5):1155-70 DOI 10.2353/ajpath.2008.070791. 
458 Koutsakos M, Kedzierska K, Subbarao K. 2019. Immune responses to avian influenza

459 viruses. Journal of Immunology 202(2):382-91 DOI 10.4049/jimmunol.1801070.

460 Kreijtz JH, de Mutsert G, van Baalen CA, Fouchier RA, Osterhaus AD, Rimmelzwaan GF.

461 2008. Cross-recognition of avian H5N1 influenza virus by human cytotoxic T-lymphocyte

462 populations directed to human influenza A virus. Journal of Virology 82(11):5161-6 DOI

$463 \quad 10.1128 / J V I .02694-07$.

464 Le MQ, Horby P, Fox A, Nguyen HT, Le Nguyen HK, Hoang PM, Nguyen KC, de Jong

465 MD, Jeeninga RE, Rogier van Doorn H, Farrar J, Wertheim HF. 2013. Subclinical avian

466 influenza A(H5N1) virus infection in human, Vietnam. Emerging Infectious Diseases

467 19(10):1674-7 DOI 10.3201/eid1910.130730.

468 Lee LY, Ha do LA, Simmons C, de Jong MD, Chau NV, Schumacher R, Peng YC,

469 McMichael AJ, Farrar JJ, Smith GL, Townsend AR, Askonas BA, Rowland-Jones S,

470 Dong T. 2008. Memory T cells established by seasonal human influenza A infection cross-

471 react with avian influenza $\mathrm{A}(\mathrm{H} 5 \mathrm{~N} 1)$ in healthy individuals. The Journal Clinical

472 Investigation 118(10):3478-90 DOI 10.1172/JCI32460.

473 Lerdsamran H, Pittayawonganon C, Pooruk P, Mungaomklang A, Iamsirithaworn S,

474 Thongcharoen P, Kositanont U, Auewarakul P, Chokephaibulkit K, Oota S,

475 Pongkankham W, Silaporn P, Komolsiri S, Noisumdaeng P, Chotpitayasunondh T,

476 Sangsajja C, Wiriyarat W, Louisirirotchanakul S, Puthavathana P. 2011. Serological

477 response to the 2009 pandemic influenza A (H1N1) virus for disease diagnosis and

478 estimating the infection rate in Thai population. PLoS One 6(1):e16164 DOI

$479 \quad$ 10.1371/journal.pone.0016164

Peer) reviewing PDF | (2020:10:53374:1:0:NEW 29 Jan 2021) 
480 Lin HT, Chuang CC, Wu HL, Chu DM, Wang YC. 2013. Characterization of cross protection 481 of swine-origin influenza virus (S-OIV) H1N1 and reassortant H5N1 influenza vaccine in 482 BALB/c mice given a single-dose vaccination. Journal of Biomedical Science 20(1):19 DOI 483 10.1186/1423-0127-20-19.

Long JS, Mistry B, Haslam SM, Barclay WS. 2019. Host and viral determinants of influenza A 485 virus species specificity. Nature Reviews Microbiology 17(2):67-81 DOI 10.1038/s41579-0180115-z.

Mbawuike IN, Zhang Y, Couch RB. 2007. Control of mucosal virus infection by influenza nucleoprotein-specific CD8+ cytotoxic T lymphocytes. Respiratory Research 8(1):44 DOI $10.1186 / 1465-9921-8-44$.

Noisumdaeng P, Pooruk P, Kongchanagul A, Assanasen S, Kitphati R, Auewarakul P, Puthavathana P. 2013. Biological properties of H5 hemagglutinin expressed by vaccinia virus vector and its immunological reactivity with human sera. Viral Immunology 26(1):4959 DOI 10.1089/vim.2012.0055.

\section{Noisumdaeng P, Pooruk P, Prasertsopon J, Assanasen S, Kitphati R, Auewarakul P,}

$$
\text { Puthavathana P. 2014. Homosubtypic and heterosubtypic antibodies against highly }
$$
pathogenic avian influenza $\mathrm{H} 5 \mathrm{~N} 1$ recombinant proteins in $\mathrm{H} 5 \mathrm{~N} 1$ survivors and non-H5N1 subjects. Virology 454-455:254-62 DOI 10.1016/j.virol.2014.02.024. protection against lethal A/HongKong/156/97 (H5N1) influenza virus infection in C57BL/6 2689. 
502 Pan M, Gao R, Lv Q, Huang S, Zhou Z, Yang L, Li X, Zhao X, Zou X, Tong W, Mao S, Zou

503 S, Bo H, Zhu X, Liu L, Yuan H, Zhang M, Wang D, Li Z, Zhao W, Ma M, Li Y, Li T,

504 Yang H, Xu J, Zhou L, Zhou X, Tang W, Song Y, Chen T, Bai T, Zhou J, Wang D, Wu

505 G, Li D, Feng Z, Gao GF, Wang Y, He S, Shu Y. 2016. Human infection with a novel, highly

506 pathogenic avian influenza A (H5N6) virus: Virological and clinical findings. Journal of

$507 \quad$ Infection 72(1):52-9 DOI 10.1016/j.jinf.2015.06.009.

508 Park SJ, Kim EH, Pascua PNQ, Kwon HI, Lim GJ, Decano A, Kim SM, Song MK, Shin

509 EC, Choi YK. 2014. Evaluation of heterosubtypic cross-protection against highly pathogenic

510 H5N1 by active infection with human seasonal influenza A virus or trivalent inactivated

511 vaccine immunization in ferret models. Journal of General Virology 95(Pt 4):793-798 DOI

$512 \quad$ 10.1099/vir.0.058636-0.

513 Peacock THP, James J, Sealy JE, Iqbal M. 2019. A global perspective on H9N2 avian influenza

$514 \quad$ virus. Viruses 11(7):620 DOI 10.3390/v11070620.

515 Peiris JS, de Jong MD, Guan Y. 2007. Avian influenza virus (H5N1): a threat to human

516 health. Clinical Microbiology Reviews 20(2):243-67 DOI 10.1128/CMR.00037-06.

517 Powell TJ, Fox A, Peng Y, Quynh Mai le T, Lien VT, Hang NL, Wang L, Lee LY, Simmons

518 CP, McMichael AJ, Farrar JJ, Askonas BA, Duong TN, Thai PQ, Thu Yen NT,

519 Rowland-Jones SL, Hien NT, Horby P, Dong T. 2012. Identification of H5N1-specific T-

520 cell responses in a high-risk cohort in vietnam indicates the existence of potential

521 asymptomatic infections. The Journal of Infectious Diseases 205(1):20-7 DOI

$522 \quad$ 10.1093/infdis/jir689.

523 Puthavathana P, Auewarakul P, Charoenying PC, Sangsiriwut K, Pooruk P, Boonnak K,

524 Khanyok R, Thawachsupa P, Kijphati R, Sawanpanyalert P. 2005. Molecular 
characterization of the complete genome of human influenza H5N1 virus isolates from

526 Thailand. Journal of General Virology 86(Pt 2):423-33 DOI 10.1099/vir.0.80368-0.

527 Puzelli S, Rossini G, Facchini M, Vaccari G, Di Trani L, Di Martino A, Gaibani P, Vocale C,

528 Cattoli G, Bennett M, McCauley JW, Rezza G, Moro ML, Rangoni R, Finarelli AC,

529 Landini MP, Castrucci MR, Donatelli I; Influenza Task Force. 2014. Human infection

530 with highly pathogenic $\mathrm{A}(\mathrm{H} 7 \mathrm{~N} 7)$ avian influenza virus, Italy, 2013. Emerging Infectious

531 Diseases 20(10):1745-9 DOI 10.3201/eid2010.140512.

532 Richards KA, Chaves FA, Sant AJ. 2009. Infection of HLA-DR1 transgenic mice with a

533 human isolate of influenza a virus $(\mathrm{H} 1 \mathrm{~N} 1)$ primes a diverse CD4 T-cell repertoire that

534 includes CD4 T cells with heterosubtypic cross-reactivity to avian (H5N1) influenza

535 virus. Journal of Virology 83(13):6566-77 DOI 10.1128/JVI.00302-09.

536 Rimmelzwaan GF, Boon AC, Voeten JT, Berkhoff EG, Fouchier RA, Osterhaus AD. 2004.

537 Sequence variation in the influenza A virus nucleoprotein associated with escape from

538 cytotoxic T lymphocytes. Virus Research 103(1-2):97-100 DOI

$539 \quad$ 10.1016/j.virusres.2004.02.020.

540 Rimmelzwaan GF, Katz JM. 2013. Immune responses to infection with H5N1 influenza

541 virus. Virus Research 178(1):44-52 DOI 10.1016/j.virusres.2013.05.011.

542 Ross KA, Loyd H, Wu W, Huntimer L, Ahmed S, Sambol A, Broderick S, Flickinger Z,

543 Rajan K, Bronich T, Mallapragada S, Wannemuehler MJ, Carpenter S, Narasimhan B.

544 2014. Hemagglutinin-based polyanhydride nanovaccines against H5N1 influenza elicit

545 protective virus neutralizing titers and cell-mediated immunity. International Journal of

$546 \quad$ Nanomedicine 10:229-43 DOI 10.2147/IJN.S72264. 
547 Roti M, Yang J, Berger D, Huston L, James EA, Kwok WW. 2008. Healthy human subjects

548 have CD4+ T cells directed against H5N1 influenza virus. Journal of Immunology

549 180(3):1758-68 DOI 10.4049/jimmunol.180.3.1758.

550 Sawai T, Itoh Y, Ozaki H, Isoda N, Okamoto K, Kashima Y, Kawaoka Y, Takeuchi Y,

551 Kida H, Ogasawara K. 2008. Induction of cytotoxic T-lymphocyte and antibody responses

552 against highly pathogenic avian influenza virus infection in mice by inoculation of

553 apathogenic H5N1 influenza virus particles inactivated with formalin. Immunology

554 124(2):155-65 DOI 10.1111/j.1365-2567.2007.02745.x.

555 Seo SH, Webster RG. 2001. Cross-reactive, cell-mediated immunity and protection of chickens

556 from lethal H5N1 influenza virus infection in Hong Kong poultry markets. Journal of

557 Virology 75(6):2516-25 DOI 10.1128/JVI.75.6.2516-2525.2001.

558 Seo SH, Peiris M, Webster RG. 2002. Protective cross-reactive cellular immunity to lethal

559 A/Goose/Guangdong/1/96-like H5N1 influenza virus is correlated with the proportion of

560 pulmonary CD8(+) T cells expressing gamma interferon. Journal of Virology 76(10):4886-90

$561 \quad$ DOI 10.1128/jvi.76.10.4886-4890.2002.

562 Sun Y, Liu J, Yang M, Gao F, Zhou J, Kitamura Y, Gao B, Tien P, Shu Y, Iwamoto A,

563 Chen Z, Gao GF. 2010. Identification and structural definition of H5-specific CTL epitopes

564 restricted by HLA-A*0201 derived from the H5N1 subtype of influenza A viruses. Journal

565 of General Virology 91(Pt 4):919-30 DOI 10.1099/vir.0.016766-0.

566 Taubenberger JK, Kash JC. 2010. Influenza virus evolution, host adaptation, and pandemic

567 formation. Cell Host \& Microbe 7(6):440-51 DOI 10.1016/j.chom.2010.05.009.

568 Thomas PG, Keating R, Hulse-Post DJ, Doherty PC. 2006. Cell-mediated protection in

569 influenza infection. Emerging Infectious Diseases 12(1):48-54 DOI 10.3201/eid1201.051237. 
570 Ungchusak K, Auewarakul P, Dowell SF, Kitphati R, Auwanit W, Puthavathana P,

571 Uiprasertkul M, Boonnak K, Pittayawonganon C, Cox NJ, Zaki SR, Thawatsupha P,

572 Chittaganpitch M, Khontong R, Simmerman JM, Chunsutthiwat S. 2005. Probable

573 person-to-person transmission of avian influenza A (H5N1). The New England Journal of

574 Medicine 352(4):333-40 DOI 10.1056/NEJMoa044021.

575 van Maurik A, Sabarth N, Dacho HS, Brühl P, Schwendinger M, Crowe BA, Noel Barrett

576 P, Kistner O, Keith Howard M. 2010. Seasonal influenza vaccine elicits heterosubtypic

577 immunity against H5N1 that can be further boosted by H5N1 vaccination. Vaccine

$578 \quad$ 28(7):1778-85 DOI 10.1016/j.vaccine.2009.12.008.

579 Webster RG, Bean WJ, Gorman OT, Chambers TM, Kawaoka Y. 1992. Evolution and $580 \quad$ ecology of influenza A viruses. Microbiology Reviews 56(1):152-79 PMID 1579108.

581 Wong SS, Yuen KY. 2006. Avian influenza virus infections in humans. Chest 129(1):156-68

$582 \quad$ DOI 10.1378/chest.129.1.156.

583 World Health Organization (WHO). 2020. Cumulative number of confirmed human cases of

584 avian influenza A(H5N1) reported to WHO. Available at

585 https://www.who.int/influenza/human_animal_interface/H5N1_cumulative_table_archives/en

$586 \quad$ /. (Accessed 12 September 2020).

587 Writing Committee of the Second World Health Organization Consultation on Clinical 588 Aspects of Human Infection with Avian Influenza A (H5N1) Virus, Abdel-Ghafar AN, 589 Chotpitayasunondh T, Gao Z, Hayden FG, Nguyen DH, de Jong MD, Naghdaliyev A, 590 Peiris JS, Shindo N, Soeroso S, Uyeki TM. 2008. Update on avian influenza A (H5N1) virus 591 infection in humans. The New England Journal of Medicine 358(3):261-73 DOI $592 \quad$ 10.1056/NEJMra0707279. 
593 Yu H, Cowling BJ, Feng L, Lau EH, Liao Q, Tsang TK, Peng Z, Wu P, Liu F, Fang VJ, 594 Zhang H, Li M, Zeng L, Xu Z, Li Z, Luo H, Li Q, Feng Z, Cao B, Yang W, Wu JT, Wang 595 Y, Leung GM. 2013. Human infection with avian influenza A H7N9 virus: an assessment of 596 clinical severity. Lancet 382(9887):138-45 DOI 10.1016/S0140-6736(13)61207-6.

597 Zhao Y, Zhang YH, Denney L, Young D, Powell TJ, Peng YC, Li N, Yan HP, Wang DY, Shu 598 YL, Kendrick Y, McMichael AJ, Ho LP, Dong T. 2012. High levels of virus-specific CD4 ${ }^{+}$ 599 T cells predict severe pandemic influenza A virus infection. American Journal Respiratory 600 and Critical Care Medicine 186(12):1292-7 DOI 10.1164/rccm.201207-1245OC.

601

602

603

604

605

606

607 


\section{Table $\mathbf{1}$ (on next page)}

Magnitude of cross-reactive T cell responses to H5N1 NP peptides in non-H5N1 subjects 
1 Table 1. Magnitude of cross-reactive T cell responses to H5N1 NP peptides in non-H5N1 subjects

\begin{tabular}{|c|c|c|c|}
\hline Subject No. & Peptide & Amino acid sequence & $\begin{array}{c}\text { ex vivo IFN- } \gamma \text { response } \\
\text { (SFCs } / 10^{6} \text { PBMCs) }\end{array}$ \\
\hline \multicolumn{4}{|c|}{ H3N2 patients (six responders from 10 patients, $60 \%$ ) } \\
\hline 2 & $\mathrm{NP}_{111-130}$ & YDKEEIRRIWRQANNGEDAT & 40 \\
\hline 6 & $\mathrm{NP}_{221-240}$ & RMCNILKGKFQTAAQRAMMD & 140 \\
\hline 7 & $\mathrm{NP}_{111-130}$ & YDKEEIRRIWRQANNGEDAT & 60 \\
\hline \multirow[t]{2}{*}{8} & $\mathrm{NP}_{221-240}$ & RMCNILKGKFQTAAQRAMMD & 62 \\
\hline & $\mathrm{NP}_{311-330}$ & QVFSLIRPNENPAHKSQLVW & 104 \\
\hline 9 & $\mathrm{NP}_{221-240}$ & RMCNILKGKFQTAAQRAMMD & 104 \\
\hline 10 & $\mathrm{NP}_{311-330}$ & QVFSLIRPNENPAHKSQLVW & 105 \\
\hline \multicolumn{4}{|c|}{ Healthy individuals (nine responders from 23 subjects, $39 \%$ ) } \\
\hline \multirow[t]{2}{*}{11} & $\mathrm{NP}_{481-498}$ & MNNEGSYFFGDNAEEYDN & 36 \\
\hline & $\mathrm{NP}_{311-330}$ & QVFSLIRPNENPAHKSQLVW & 52 \\
\hline \multirow[t]{2}{*}{13} & $\mathrm{NP}_{221-240}$ & RMCNILKGKFQTAAQRAMMD & 37 \\
\hline & $\mathrm{NP}_{111-130}$ & YDKEEIRRIWRQANNGEDAT & 28 \\
\hline 17 & $\mathrm{NP}_{111-130}$ & YDKEEIRRIWRQANNGEDAT & 32 \\
\hline 19 & $\mathrm{NP}_{481-498}$ & MNNEGSYFFGDNAEEYDN & 22 \\
\hline 27 & $\mathrm{NP}_{111-130}$ & YDKEEIRRIWRQANNGEDAT & 53 \\
\hline 28 & $\mathrm{NP}_{481-498}$ & MNNEGSYFFGDNAEEYDN & 28 \\
\hline 29 & $\mathrm{NP}_{221-240}$ & RMCNILKGKFQTAAQRAMMD & 71 \\
\hline 30 & $\mathrm{NP}_{401-420}$ & ASAGQISVQPTFSVQRNLPF & 45 \\
\hline \multirow[t]{2}{*}{31} & $\mathrm{NP}_{221-240}$ & RMCNILKGKFQTAAQRAMMD & 37 \\
\hline & $\mathrm{NP}_{401-420}$ & ASAGQISVQPTFSVQRNLPF & 64 \\
\hline
\end{tabular}

2 
Table 2 (on next page)

Amino acid identity and cross reactivity to H5N1 NP peptides 
1 Table 2. Amino acid identity and cross reactivity to H5N1 NP peptides

2

\begin{tabular}{|c|c|c|c|}
\hline Epitope / subtype & Sequence & Cross reactivity & Frequency of recognition \\
\hline \multicolumn{4}{|l|}{$\mathrm{NP}_{1-20}$} \\
\hline H5 & MASQGTKRSYEQMETGGERQ & - & $1 *$ survivor \\
\hline H3 & 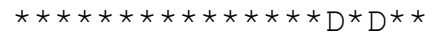 & & \\
\hline H1 & 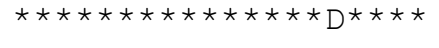 & & \\
\hline H1pdm & 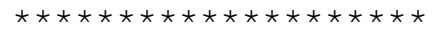 & & \\
\hline \multicolumn{4}{|l|}{$\mathrm{NP}_{111-130}$} \\
\hline H5 & YDKEEIRRIWRQANNGEDAT & + & 5 ( $1 *$ survivor $)$ \\
\hline $\mathrm{H} 3$ & 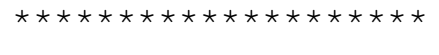 & & \\
\hline $\mathrm{H} 1$ & 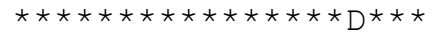 & & \\
\hline H1pdm & 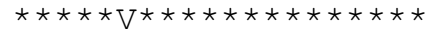 & & \\
\hline \multicolumn{4}{|l|}{$\mathrm{NP}_{221-240}$} \\
\hline H5 & RMCNI LKGKFQTAAQRAMMD & + & 6 \\
\hline $\mathrm{H} 3$ & 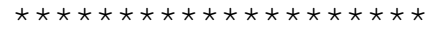 & & \\
\hline H1 & 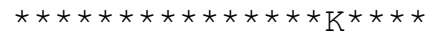 & & \\
\hline H1pdm & 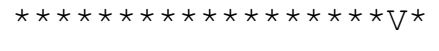 & & \\
\hline \multicolumn{4}{|l|}{$\mathrm{NP}_{311-330}$} \\
\hline H5 & QVFSLIRPNENPAHKSQLVW & + & 3 \\
\hline H3 & 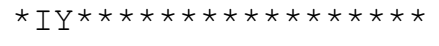 & & \\
\hline H1 & 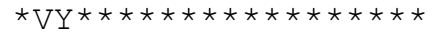 & & \\
\hline H1pdm & 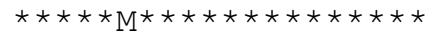 & & \\
\hline \multicolumn{4}{|l|}{$\mathrm{NP}_{401-420}$} \\
\hline H5 & ASAGQISVQPTFSVQRNLPF & + & 2 \\
\hline H3 & 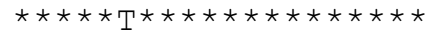 & & \\
\hline $\mathrm{H} 1$ & 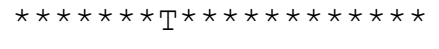 & & \\
\hline H1pdm & 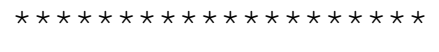 & & \\
\hline \multicolumn{4}{|l|}{$\mathrm{NP}_{411-430}$} \\
\hline H5 & TFSVQRNLPFERAT IMAAFT & - & $1 *$ survivor \\
\hline $\mathrm{H} 3$ & 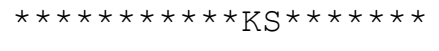 & & \\
\hline H1 & 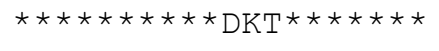 & & \\
\hline H1pdm & 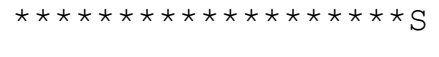 & & \\
\hline \multicolumn{4}{|l|}{$\mathrm{NP}_{481-498}$} \\
\hline H5 & MNNEGSYFFGDNAEEYDN & + & 3 \\
\hline H3 & 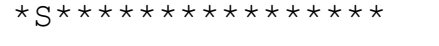 & & \\
\hline H1 & 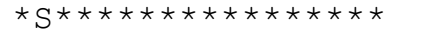 & & \\
\hline H1pdm & 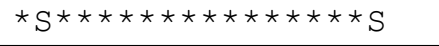 & & \\
\hline
\end{tabular}

3 Note $*$ H5N1 survivor subject 
4 - NP from H5N1 strain A/Thailand/1(KAN-1)/2004 (H5N1) (accession no. AAV35112); H3N2 strain 5 A/Brisbane/10/2007 (H3N2) (accession no. ACO95274); H1N1 strain A/New Caledonia/20/1999 (H1N1) (accession 6 no. ABW81621); H1N1pdm strain A/Thailand/104/2009 (H1N1) (accession no. ACR23306)

7 - Cross reactivity: (-) epitope recognized by H5N1 survivor only; (+) epitope recognition by H5N1 survivor 8 and/or non-H5N1 subjects

9 
Figure 1

Total magnitude of T cell responses against H5N1 NP, M and HA peptides in sequential PBMC samples from four H5N1 survivors as measured by IFN- $\gamma$ ELISpot assay.

The IFN- $\gamma$ producing T cells against H5N1 overlapping peptides of NP (A), M (B) and HA (C) are indicated. Survivor nos.1 and 2 had higher magnitude of T cell responses against NP and M peptides than survivor nos. 3 and 4 . 
A)

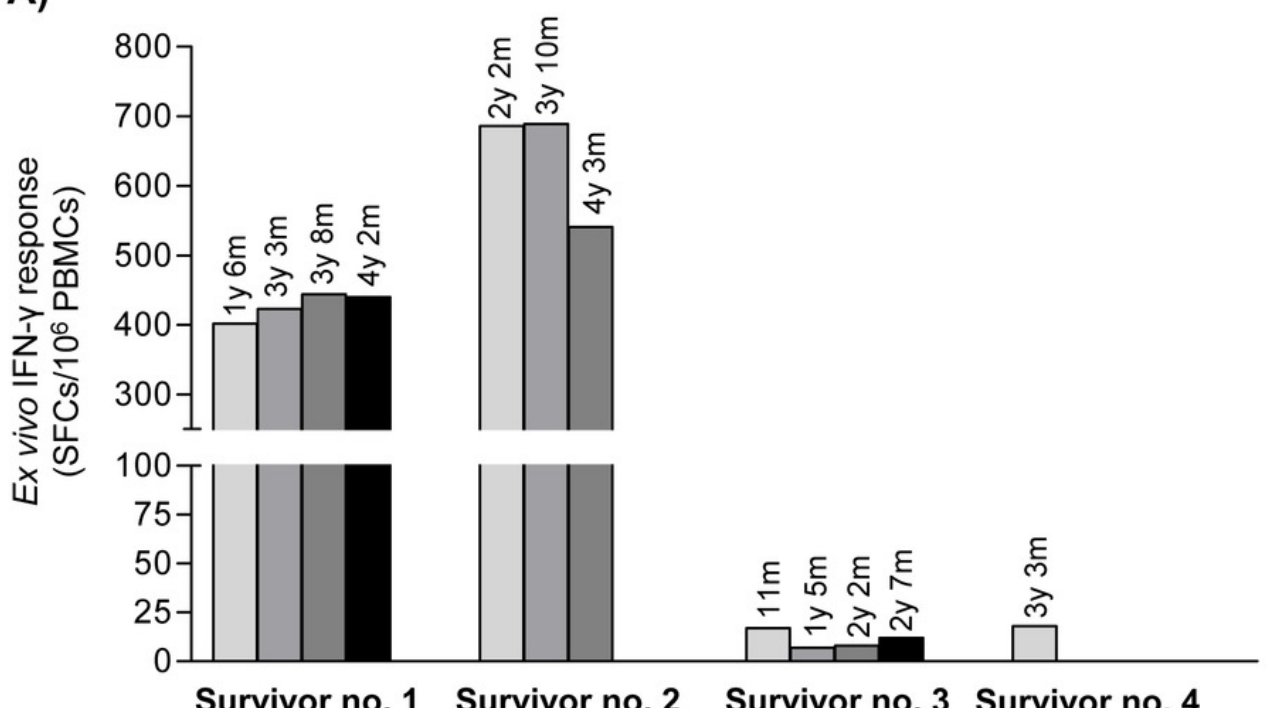

Survivor no. 1 Survivor no. 2 Survivor no. 3 Survivor no. 4

\section{B)}

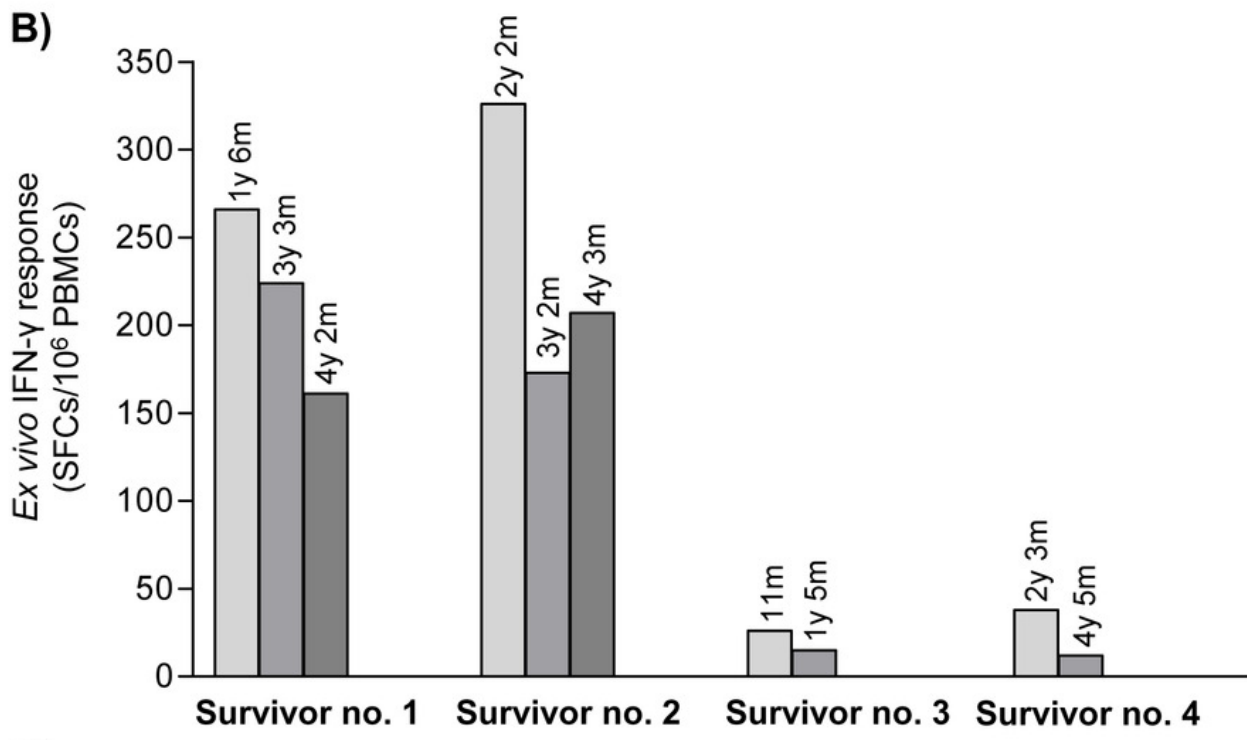

C)

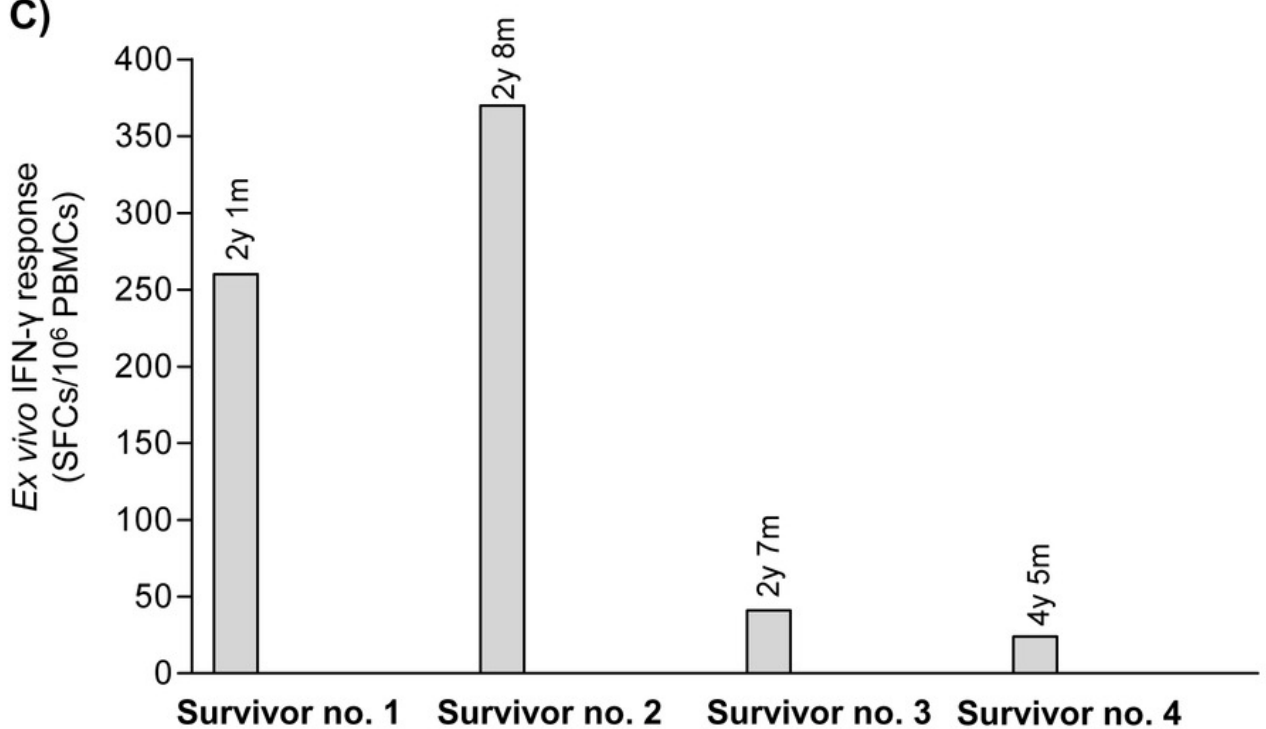


Figure 2

Ex vivo IFN-y responses and longevity of $\mathrm{H} 5 \mathrm{~N} 1$ virus-specific T cells against NP, $\mathrm{M}$ and $\mathrm{HA}$ individual peptides in H5N1 survivors.

The responses of peptide-specific T cells of survivor no. 1 (A) and survivor no. 2 (B) are shown as determined by IFN- $\gamma$ ELISpot assay.
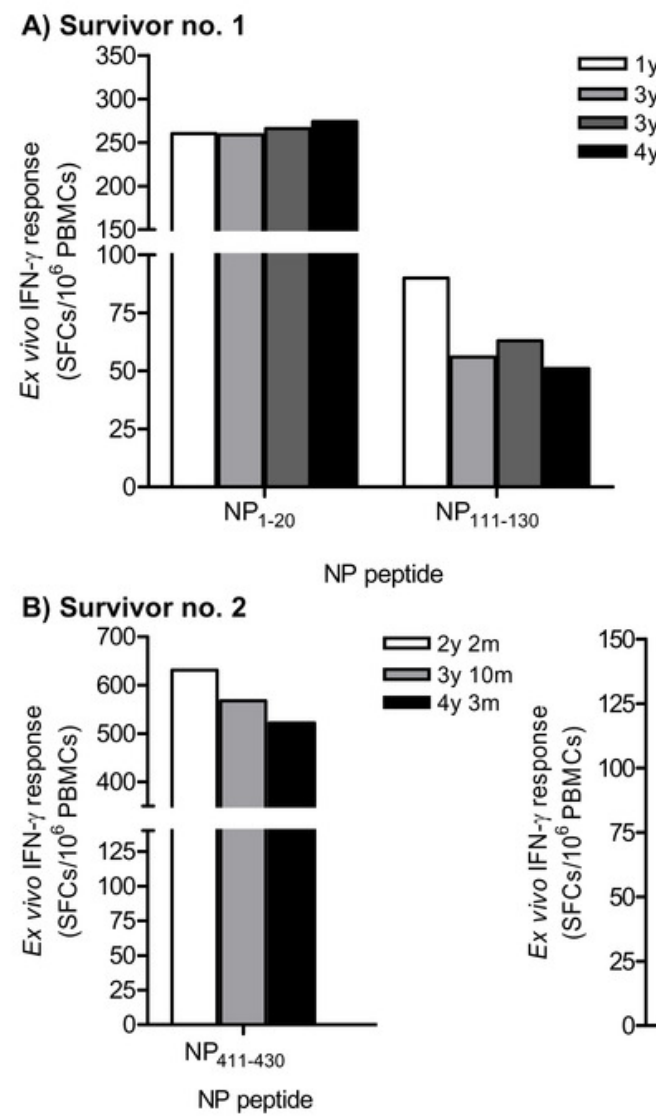

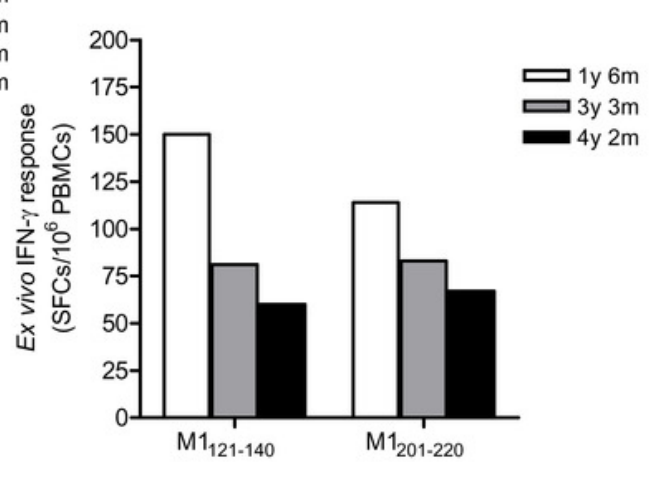

M peptide

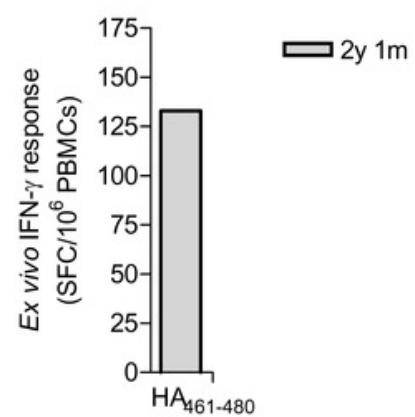

HA peptide
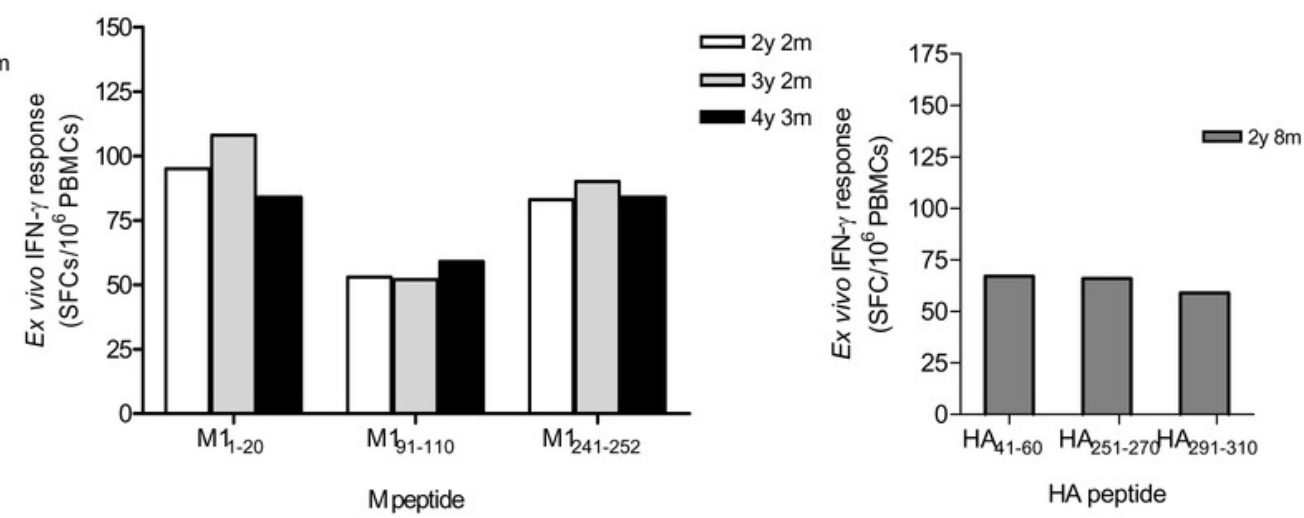
Figure 3

Total magnitude of IFN- $\gamma$ cross-reactive T cell responses in H3N2 patients and healthy individuals.

There was statistically significant difference in mean of magnitude of responses (SFCs/10 PBMCs) between two groups (Mann-Whitney $U$ test $p<0.05$ ).

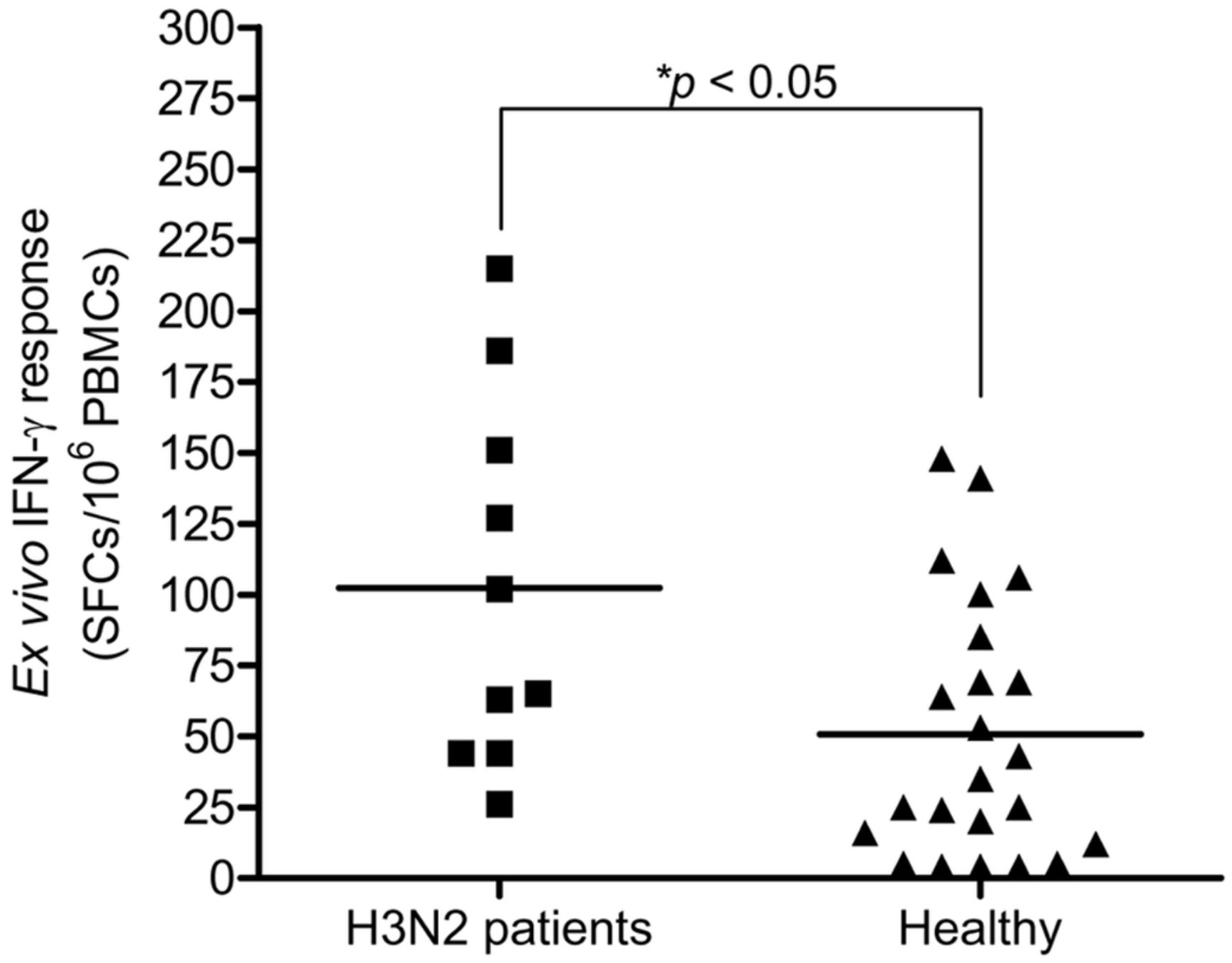

non-H5N1 subjects 


\section{Figure 4}

Polyfunctional analysis of effector $\mathrm{NP}_{411-430}$-specific $\mathrm{T}$ cells.

The T cell function which singly or simultaneously produced IFN- $\gamma$ and TNF- $\alpha$ (A) and/or upregulation of CD107a degranulation marker (B) in survivor no. 2 are shown. The percentages of both specific $\mathrm{CD}^{+}$and $\mathrm{CD8}^{+} \mathrm{T}$ cells that expressed IFN $-\gamma^{+}, \mathrm{TNF}-\alpha^{+}$and/or CD107a markedly increased in recognition of the target cells pulsed with peptide or infected with rVac-NP virus. 
A $\quad T$ cell line

$+$ unpulsed TBCL
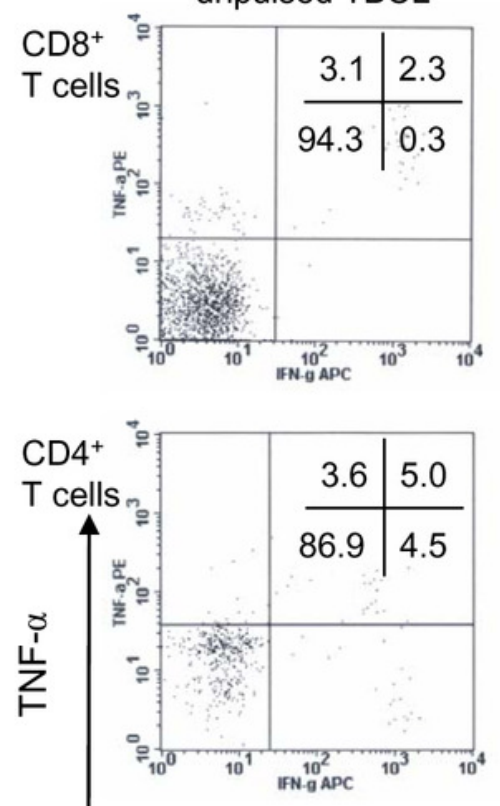

IFN- $\gamma$
T cell line

peptide pulsed TBCL rVac-pSC11 infected TBCL
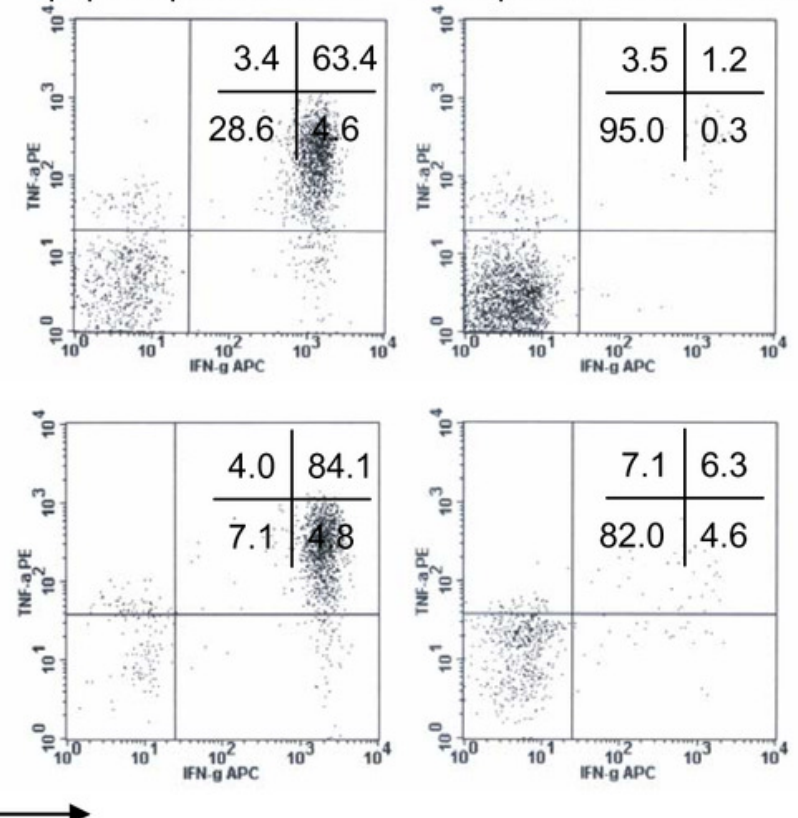

T cell line

$+$ rVac-NP infected TBCL
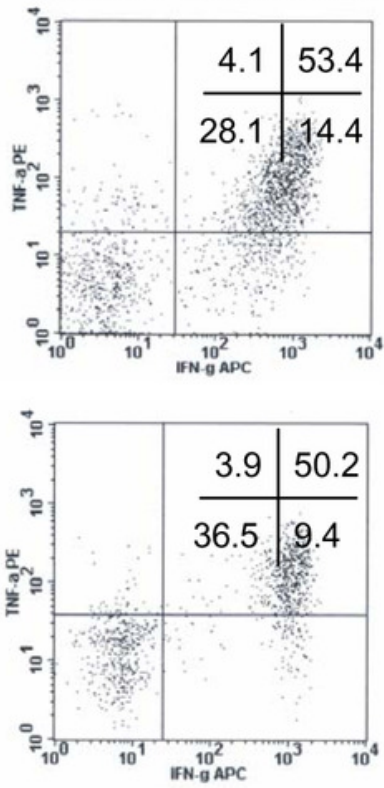

B
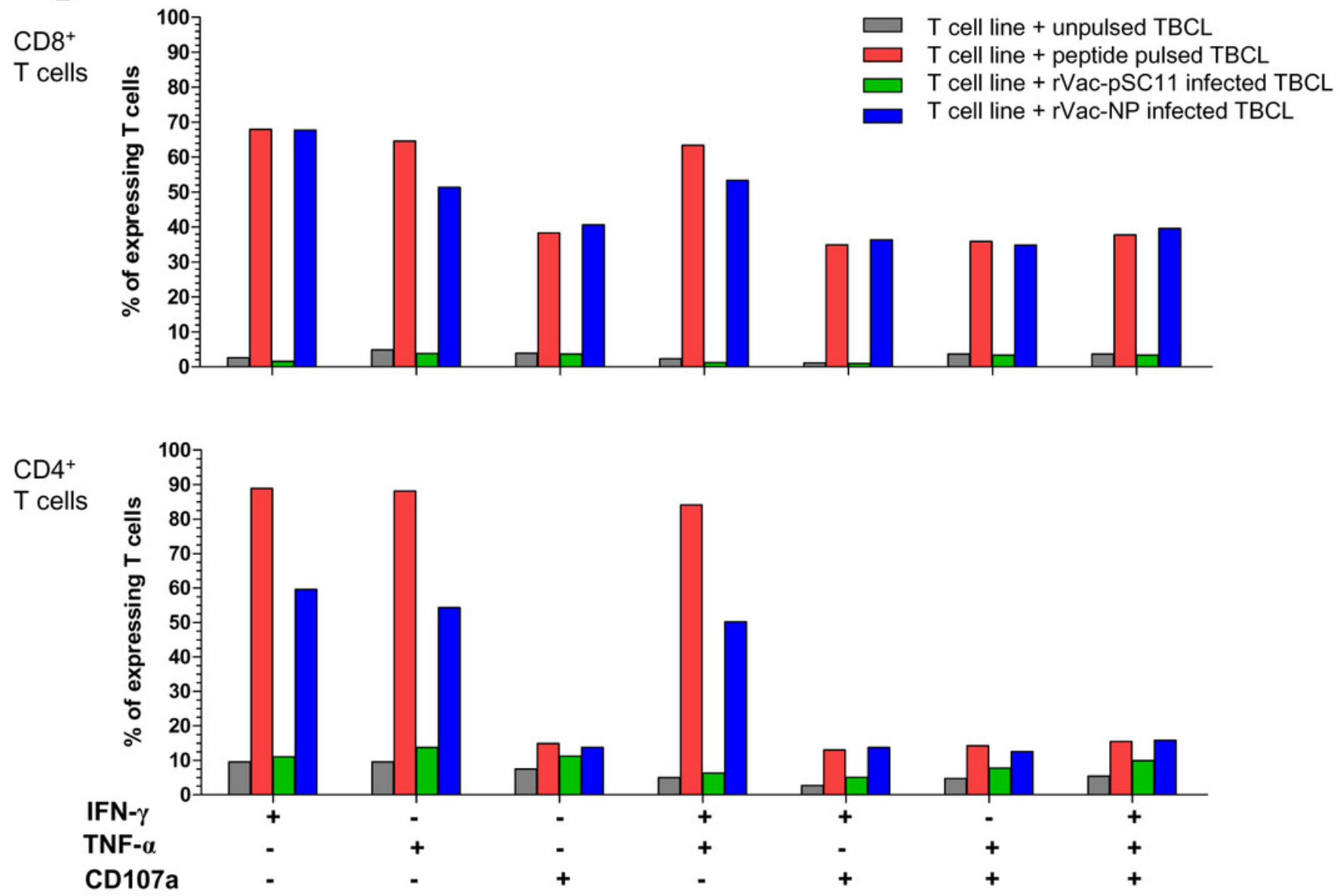